Article

\title{
Biological Response to Macroporous Chitosan-Agarose Bone Scaffolds Comprising Mg- and Zn-Doped Nano-Hydroxyapatite
}

\author{
Paulina Kazimierczak ${ }^{1}$, Joanna Kolmas ${ }^{2}(D)$ and Agata Przekora ${ }^{1, *(D)}$ \\ 1 Department of Biochemistry and Biotechnology, Medical University of Lublin, Chodzki 1 Street, \\ 20-093 Lublin, Poland \\ 2 Department of Analytical Chemistry and Biomaterials, Medical University of Warsaw, Banacha 1 Street, \\ 02-097 Warsaw, Poland \\ * Correspondence: agata.przekora@umlub.pl; Tel.: +48-81-448-7026
}

Received: 30 June 2019; Accepted: 4 August 2019; Published: 6 August 2019

check for updates

\begin{abstract}
Modification of implantable scaffolds with magnesium and zinc for improvement of bone regeneration is a growing trend in the engineering of biomaterials. The aim of this study was to synthesize nano-hydroxyapatite substituted with magnesium $\left(\mathrm{Mg}^{2+}\right)(\mathrm{HA}-\mathrm{Mg})$ and zinc $\left(\mathrm{Zn}^{2+}\right)$ (HA-Zn) ions in order to fabricate chitosan-agarose-hydroxyapatite (HA) scaffolds (chit/aga/HA) with improved biocompatibility. Fabricated biomaterials containing $\mathrm{Mg}^{2+}$ or $\mathrm{Zn}^{2+}$ were tested using osteoblasts and mesenchymal stem cells to determine the effect of incorporated metal ions on cell adhesion, spreading, proliferation, and osteogenic differentiation. The study was conducted in direct contact with the scaffolds (cells were seeded onto the biomaterials) and using fluid extracts of the materials. It demonstrated that incorporation of $\mathrm{Mg}^{2+}$ ions into chit/aga/HA structure increased spreading of the osteoblasts, promoted cell proliferation on the scaffold surface, and enhanced osteocalcin production by mesenchymal stem cells. Although biomaterial containing $\mathrm{Zn}^{2+}$ did not improve cell proliferation, it did enhance type I collagen production by mesenchymal stem cells and extracellular matrix mineralization as compared to cells cultured in a polystyrene well. Nevertheless, scaffolds made of pure HA gave better results than material with $\mathrm{Zn}^{2+}$. Results of the experiments clearly showed that modification of the chit/aga/HA scaffold with $\mathrm{Zn}^{2+}$ did not have any positive impact on cell behavior, whereas, incorporation of $\mathrm{Mg}^{2+}$ ions into its structure may significantly improve biocompatibility of the resultant material, increasing its potential in biomedical applications.
\end{abstract}

Keywords: mesenchymal stem cells; osteoblasts; osteogenic differentiation; cell spreading; proliferation; tissue engineering

\section{Introduction}

In recent years, there has been growing interest in bone tissue engineering due to a high clinical demand for biocompatible bone scaffolds and novel biomaterials. A common approach to bone tissue engineering involves the development of three-dimensional porous scaffolds that support osteoblasts/osteoprogenitor cell adhesion, proliferation, and differentiation at the implantation site. Biomaterials are often composed of ceramics (calcium phosphates and bioglass) that imitate the inorganic part of a bone, i.e., hydroxyapatite (HA), polymers which mimic the flexible organic matrix of the bone, or their composites [1,2]. Among calcium phosphates, synthetic HA is the most widely used and is characterized by good osteoinductivity and bioactivity. Unfortunately, HA ceramic is often fragile and possesses weak mechanical properties [3]. Therefore, a combination of bioceramics with polymers is of great interest in the engineering of biomaterials as it results in better surgical handiness, mechanical properties, and degradability of the resultant biomaterial [1]. 
In an attempt to achieve successful bone tissue regeneration, scientists have been studying the role of small molecules (e.g., growth factors and cytokines) and metal ions in the regeneration process. As a consequence, modification of implantable scaffolds with metal or nonmetal (fluoride) ions is a growing trend in the engineering of biomaterials [2]. One of the commonly used methods to incorporate ions in a biomaterial structure is the substitution of HA or bioglass with various elements during their fabrication process, e.g., magnesium $\left(\mathrm{Mg}^{2+}\right)$, zinc $\left(\mathrm{Zn}^{2+}\right)$, cobalt $\left(\mathrm{Co}^{2+}\right)$, lithium $\left(\mathrm{Li}^{+}\right)$, strontium $\left(\mathrm{Sr}^{2+}\right)$, copper $\left(\mathrm{Cu}^{2+}\right)$, and fluoride $\left(\mathrm{F}^{-}\right)$. Doping of different ions with bioceramics contributes to the improvement of biological properties of the resultant material, and thereby to the enhancement of regeneration of bone tissue within the implantable site. Moreover, the degree of ions loaded into the scaffolds and the controlled release of the loaded ions to the injured tissue are very significant for appropriate therapeutic effects $[2,3]$.

Among all of the metal ions, $\mathrm{Mg}^{2+}$ and $\mathrm{Zn}^{2+}$ are most often used in the engineering of biomaterials to improve the osteoconductivity of the scaffolds. $\mathrm{Mg}^{2+}$ is a very abundant element in the human body, which is essential for many physiological functions, including bone metabolism. $\mathrm{Mg}^{2+}$-doped bioceramic has been shown to trigger accelerated bone tissue regeneration in vitro and in vivo [4]. Previous studies revealed that $\mathrm{Mg}^{2+}$ ions influence osteogenesis via enhancing osteogenic gene expression, i.e., osteocalcin (OC), runt-related transcription factor 2 (Runx-2), insulin-like growth factor 1 (IGF-1), and osseointegration in vivo [5]. It has also been shown that $\mathrm{Mg}^{2+}$ ions enhance the cell proliferation rate of human bone marrow-derived stem cells (BMDSCs), up-regulate expression of genes for collagen and vascular endothelial growth factor (VEGF), and stimulate bone extracellular matrix (ECM) mineralization [6]. Furthermore, substitution of bioceramics with $\mathrm{Mg}^{2+}$ supports cell adhesion and spreading [7].

Another essential trace element involved in bone metabolism is $\mathrm{Zn}^{2+}$, which regulates the expression of genes related to osteogenic differentiation, e.g., Runx-2, bone alkaline phosphatase (bALP), type I collagen (Col I), OC, and osteopontin [8]. It has also been demonstrated that $\mathrm{Zn}^{2+}$ ions enhance cell proliferation, bALP activity, and collagen synthesis in mouse calvarial preosteoblast cell line (MC3T3-E1) preosteoblasts [9]. Importantly, biomaterials containing $\mathrm{Zn}^{2+}$ not only promote bone formation and mineralization, but also inhibit osteoclasts-mediated bone resorption $[8,10]$, have anti-inflammatory activity (through their ability to antagonize TNF- $\alpha$ ) [4], and have antibacterial properties [2].

Considering the biological activities of $\mathrm{Mg}^{2+}$ and $\mathrm{Zn}^{2+}$ and their impact on the bone regeneration process, the modification of bone scaffolds with the above-mentioned metal ions is highly justified. The goal of this work was to synthesize HA nanopowders substituted with $\mathrm{Mg}^{2+}(\mathrm{HA}-\mathrm{Mg})$ and $\mathrm{Zn}^{2+}$ (HA-Zn) ions in order to fabricate macroporous chitosan-agarose-HA scaffolds (chit/aga/HA) with improved biocompatibility. Moreover, it was hypothesized that the scaffold containing both $\mathrm{Mg}^{2+}$ and $\mathrm{Zn}^{2+}$ ions in its structure could exhibit a synergic effect on the biological response. Thus, biomaterial comprised of a mix of HA-Mg and HA-Zn was also fabricated. The scaffolds were prepared based on the procedure described in a Polish patent application no. P.426788 which used a gas-foaming agent in combination with the lyophilization process to produce material characterized by high, open and interconnected porosity. It is noteworthy that both the production method of the bone scaffolds and also their composition are innovative since there are no studies in the literature describing biomaterials made of a chitosan-agarose cryogel matrix reinforced with HA nanopowder. Scientific reports published by other authors present biomaterials for potential bone regenerations which were fabricated by applying completely different production methods and using only two of the mentioned components, e.g., scaffolds composed of only chitosan and hydroxyapatite [11,12], agarose and hydroxyapatite [13-15] or chitosan and agarose [16].

This study conducts a comprehensive analysis of biological responses and the production of bone scaffolds, with the aim of determining the effect of $\mathrm{Mg}^{2+}$ and $\mathrm{Zn}^{2+}$ incorporated into the structure of the biomaterials on osteoblast adhesion, spreading, and proliferation, as well as on osteogenic differentiation of mesenchymal stem cells. This research was conducted in direct contact with the 
scaffolds (cells were seeded onto the biomaterials) and using fluid extracts of the materials to assess the effect of the released ions on cell behavior.

\section{Results and Discussion}

\subsection{Characterization of Calcium Phosphate Ceramics (NanoHA)}

All of the produced HA nanopowders were similar in size and morphology (Figure 1). The crystals were slightly irregular, plate-like, with an approximate diameter of $50-80 \mathrm{~nm}$. Moreover, the crystals on the surface of all the samples tended to merge into dense clusters. It is important to note that the use of the wet precipitation method usually results in the formation of very fine apatite nanocrystals the size of $10-50 \mathrm{~nm}[17,18]$. Moreover, the crystal shapes and sizes depend on many factors including the temperature and concentration of reagents, the addition of ion, and the temperature of calcination [19]. The obtained powders, after filtering and drying, were calcined at $1000{ }^{\circ} \mathrm{C}$ for $1 \mathrm{~h}$ in a furnace. The heating process resulted in crystals that were quite large and with rounded shapes.

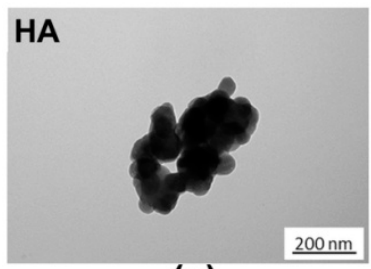

(a)

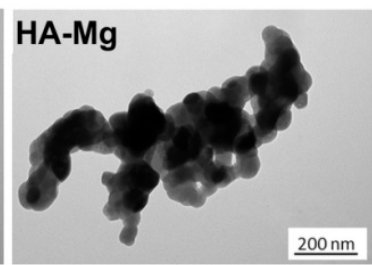

(b)

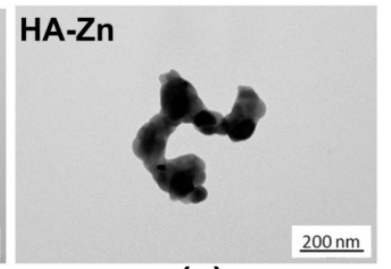

(c)

Figure 1. Transmission electron microscope (TEM) images of the obtained powders: (a) hydroxyapatite (HA), (b) HA substituted with magnesium (HA-Mg), and (c) HA substituted with zinc (HA-Zn) (scale bar $=200 \mathrm{~nm})$.

The elemental analysis showed that the magnesium content in the HA-Mg sample was approximately $0.022 \pm 0.002 \mathrm{~mol}$ and the zinc content in the HA-Zn sample was $0.028 \pm 0.003 \mathrm{~mol}$ which is $73.3 \%$ and $93.3 \%$ of the assumed values, respectively. The powder X-ray diffraction (PXRD) patterns of HA, HA-Mg, and HA-Zn nanopowders are presented in Figure 2a. It is evident that all the materials were comprised of hydroxyapatite as one crystalline phase (all the reflections conforming well to the standard stoichiometric hydroxyapatite, JCPDS 09-0432). All the patterns exhibited narrow reflections related to highly crystalline materials $[19,20]$. It seems that the introduction of magnesium or zinc did not considerably affect the apatitic structure. The unit cell parameters and the calculated crystallite sizes obtained from PXRD measurements are presented in Table 1.

Table 1. Parameters obtained from the PXRD patterns: unit cell parameters a and $\mathrm{c}(\mathrm{nm})$ and average crystallite sizes determined from (002) reflection.

\begin{tabular}{ccccc}
\hline Nanopowder & & HA & HA-Mg & HA-Zn \\
\hline \multirow{2}{*}{ Unit cell parameters $(\mathrm{nm}) *$} & $\mathrm{a}$ & 0.943 & 0.9425 & 0.9420 \\
\cline { 2 - 5 } & $\mathrm{c}$ & 0.6872 & 0.6853 & 0.6818 \\
\hline Crystal size $(\mathrm{nm})$ & & $65 \pm 5$ & $58 \pm 4$ & $64 \pm 6$ \\
\hline
\end{tabular}

* The error does not exceed $0.3 \%$. 


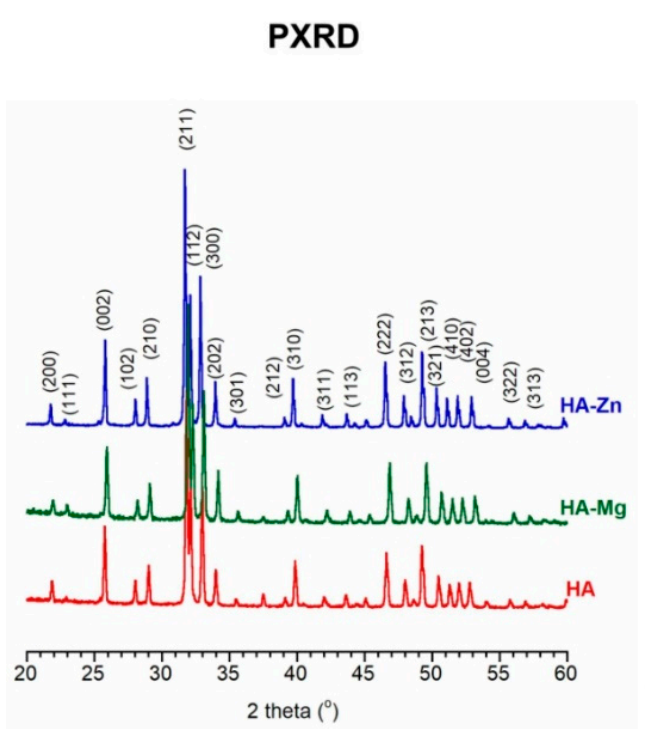

(a)

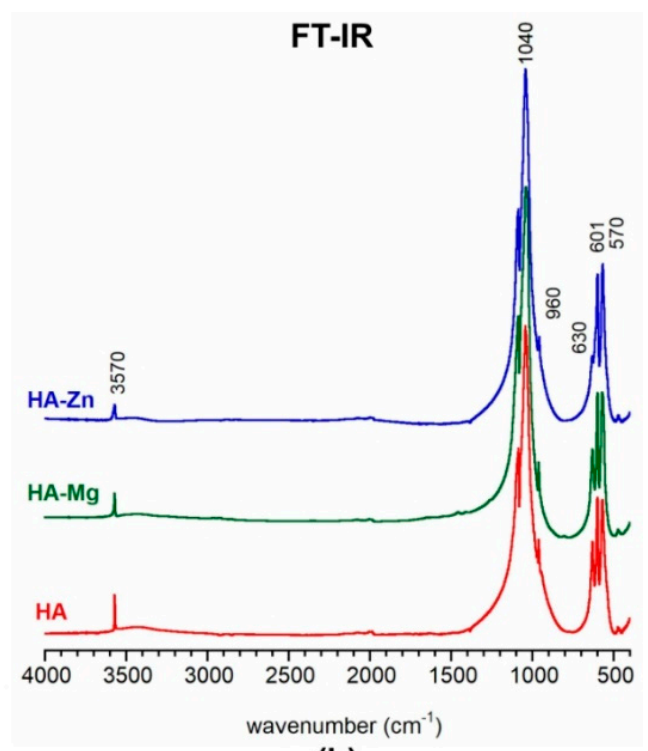

(b)

Figure 2. Powder X-ray diffraction (PXRD) patterns (a) and Fourier-transform infrared spectroscopy (FT-IR) spectra (b) of the synthesized calcium phosphate ceramics (nanoHA) powders.

Fourier-transform infrared spectroscopy (FT-IR) spectra of the produced HA nanopowders are shown in Figure $2 \mathrm{~b}$. In the $1200-900 \mathrm{~cm}^{-1}$ and $603-500 \mathrm{~cm}^{-1}$ ranges, intense, narrow and well separated bands from orthophosphates are visible $\left(v_{1}+v_{3}\right.$ and $v_{4}$, respectively). These bands are characteristic of well crystalline hydroxyapatite [20]. Moreover, the bands at $3570 \mathrm{~cm}^{-1}$ and $633 \mathrm{~cm}^{-1}$ correspond to stretching and librational bands of structural hydroxyl $(\mathrm{OH})$ groups, respectively. It should be noted that the relative intensity of $\mathrm{OH}$ bands was the lowest in the HA-Zn spectrum. This may indicate the lowest content of these groups in the structural $\mathrm{OH}$ groups columns. According to the literature, the mechanism of zinc substitution into the apatitic crystal lattice may be complex, i.e., $\mathrm{Zn}^{2+}$ may replace $\mathrm{Ca}^{2+}$ cations in the crystal core or may be introduced into the structural $\mathrm{OH}$ columns [21,22]. Thus, the relative decrease of the $\mathrm{OH}$ content may be related to the zinc insertion between two oxygen atoms and the release of $\mathrm{H}^{+}$[21]:

$$
\mathrm{Zn}^{2+}+\mathrm{Ca}_{10}\left(\mathrm{PO}_{4}\right)_{6}(\mathrm{OH})_{2} \rightarrow \mathrm{ZnCa}_{10}\left(\mathrm{PO}_{4}\right)_{6} \mathrm{O}_{2}+2 \mathrm{H}^{+}
$$

All the spectra were devoid of bands originating from vibrations of $\mathrm{OH}$ groups of water. This was due to the use of high temperature $\left(1000^{\circ} \mathrm{C}\right)$ for sample calcination after wet synthesis. For the same reason, there were no bands from carbonates (at approximately $1500-1400 \mathrm{~cm}^{-1}$ and $870 \mathrm{~cm}^{-1}$ ).

The following synthesized nanoHA powders were used for the production of the following highly macroporous bone scaffolds: chit/aga/HA, chit/aga/HA-Mg, chit/aga/HA-Zn, and chit/aga/HA-Mg/Zn which contained the 1:1 mixture of HA-Mg and HA-Zn. Figure 3 shows the sample stereoscopic microscope image of the produced biomaterial. There were no significant differences in microstructure and topography between respective scaffolds comprising metal-doped HA. The surface of all scaffolds was characterized by high roughness and macroporosity. 


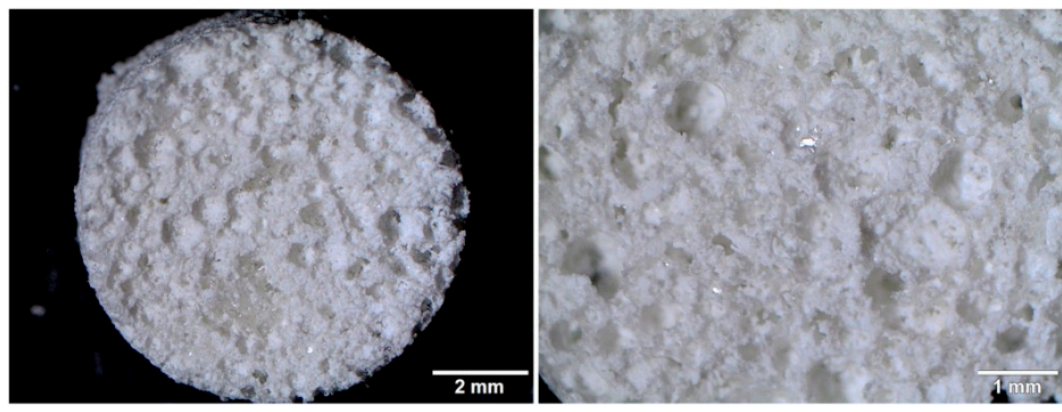

Figure 3. Microstructure of the chitosan-agarose-HA (chit/aga/HA) scaffold visualized by a stereoscopic microscope.

\subsection{Evaluation of Ions Concentration in Scaffolds Extracts}

The $\mathrm{Mg}^{2+}$ and $\mathrm{Zn}^{2+}$ ion concentrations in the prepared scaffold extracts are shown in Table 2. The chit/aga/HA (control material) and chit/aga/HA-Zn scaffolds exhibited a slight uptake of $\mathrm{Mg}^{2+}$ ions from the culture medium after $24 \mathrm{~h}$ incubation at $37{ }^{\circ} \mathrm{C}$, whereas, chit/aga/HA-Mg and chit/aga/HA-Mg/Zn scaffolds released $\mathrm{Mg}^{2+}$ ions. Chit/aga/HA-Zn and chit/aga/HA-Mg/Zn samples caused an increase in the $\mathrm{Zn}^{2+}$ ion concentration in the medium, however chit/aga/HA-Zn released significantly more ions as compared to the chit/aga/HA-Mg/Zn.

Table 2. $\mathrm{Mg}^{2+}$ and $\mathrm{Zn}^{2+}$ ion concentrations $[\mu \mathrm{g} / \mathrm{mL}]$ in scaffold extracts prepared by $24 \mathrm{~h}$ incubation of the materials in culture medium.

\begin{tabular}{cccccc}
\hline $\begin{array}{c}\text { Conc. } \\
(\mu \mathrm{g} / \mathrm{mL})\end{array}$ & $\begin{array}{c}\text { Control Culture } \\
\text { Medium }\end{array}$ & Chit/Aga/HA & Chit/Aga/HA-Mg & Chit/Aga/HA-Zn & Chit/Aga/HA-Mg/Zn \\
\hline $\mathrm{Mg}^{2+}$ & $29.12 \pm 3.14$ & $16.90 \pm 0.83 * \$$ & $41.04 \pm 1.09 *$ & $21.36 \pm 1.50 * \# \$$ & $36.16 \pm 2.67 *$ \\
$\mathrm{Zn}^{2+}$ & $0.16 \pm 0.06$ & $0.11 \pm 0.02 \$ \&$ & $0.12 \pm 0.03$ & $4.42 \pm 0.25 * \# \$$ & $0.64 \pm 0.13 * \#$ \\
\hline
\end{tabular}

* statistically significant results as compared to the control medium; " statistically significant results as compared to chit/aga/HA-Mg; ${ }^{\$}$ statistically significant results as compared to chit/aga/HA-Mg/Zn; ${ }^{\&}$ statistically significant results as compared to chit/aga/HA-Zn $(P<0.05$, one-way ANOVA followed by Tukey's test).

\subsection{In Vitro Cell Culture Experiments}

\subsubsection{Cytotoxicity Assessment}

The MTT test showed that scaffolds were nontoxic to MC3T3-E1 osteoblasts (Figure 4a). After $24 \mathrm{~h}$ exposure time, the chit/aga/HA-Mg extract significantly increased cell metabolism as compared to other extracts and the control medium $(P<0.0001$ as compared to the control medium and extracts of chit/aga/HA and chit/aga/HA-Zn, $P=0.0004$ as compared to chit/aga/HA-Mg/Zn extract). This is in agreement with studies performed by $\mathrm{He}$ et al. that revealed the ability of $\mathrm{Mg}^{2+}$ ions to increase osteoblasts viability via enhancing gap junction intercellular communication between the cells which are responsible for transmitting signals [23]. Whereas, after $48 \mathrm{~h}$ exposure time, the viability of cells was near $100 \%$ for all investigated extracts (no statistically significant results were observed). Live-dead staining of MC3T3-E1 osteoblasts cultured on the surface of the biomaterials for $48 \mathrm{~h}$ confirmed nontoxicity of the scaffolds (Figure $4 b$ ).

Confocal laser scanning microscope (CLSM) images presented a great number of viable cells (green fluorescence), which were flattened and well attached to all scaffolds, confirming their good adhesion. Interestingly, the number of osteoblasts attached to the chit/aga/HA-Mg scaffold was noticeably higher as compared to other scaffolds. Thus, the tendency in both experiments (i.e., the indirect cytotoxicity test with the use of scaffolds extracts and the cytotoxicity test in direct contact with the biomaterials) was the same since the bone scaffold comprising HA-Mg, as well as extract enriched with $\mathrm{Mg}$ ions, had a positive effect on cell viability. 


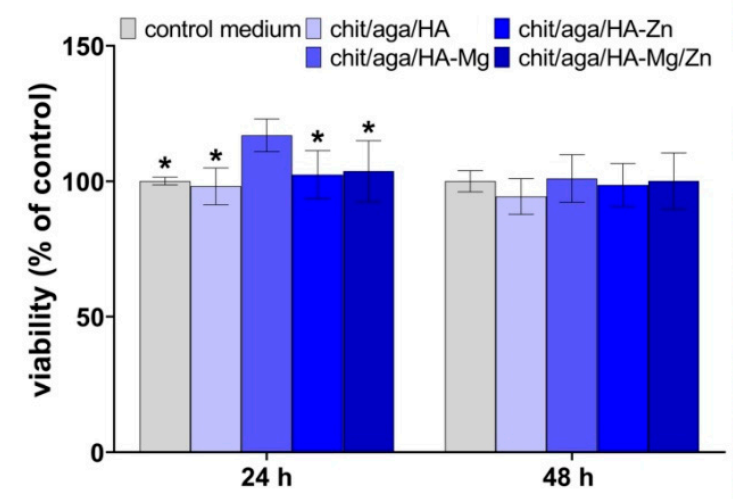

(a)

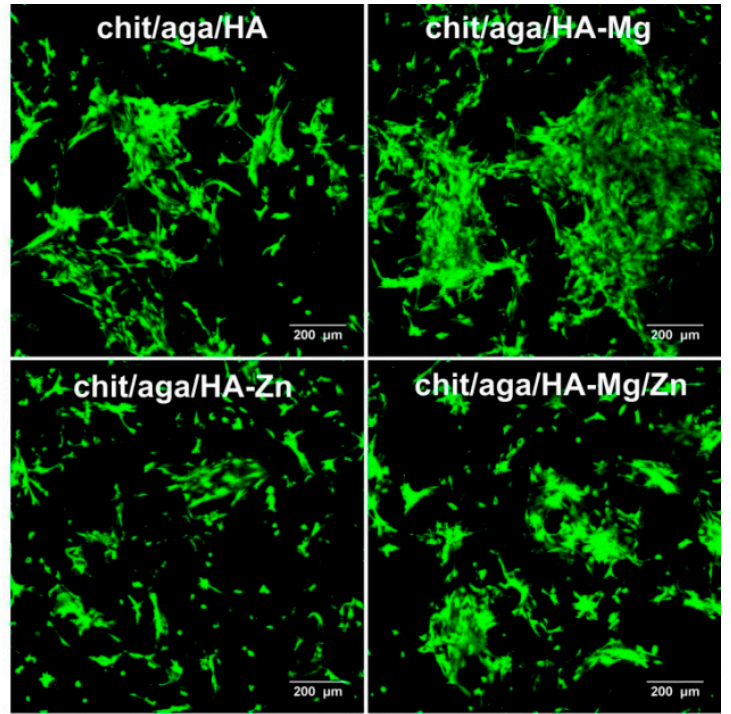

(b)

Figure 4. Cytotoxicity assessment of the scaffolds against mouse calvarial preosteoblast cell line (MC3T3-E1) cells: (a) MTT assay performed using scaffolds extracts (*statistically significant results as compared to chit/aga/HA-Mg extract, $P<0.05$, one-way ANOVA followed by Tukey's test); (b) confocal laser scanning microscope (CLSM) images presenting live-dead staining (viable cells, green fluorescence and dead cells, red fluorescence) of MC3T3-E1 cells cultured for $48 \mathrm{~h}$ on the surface of the scaffolds; magnified 100×, scale bar $=200 \mu \mathrm{m}$.

\subsubsection{Cell Adhesion and Spreading}

The CLSM images showed that cells cultured on the biomaterials, as well as in the polystyrene wells (PS wells), in the presence of scaffolds extracts were well spread and had flattened morphology. Nevertheless, differences in the shape of the osteoblasts were observed between the cells cultured directly on the scaffolds and in the PS wells, which resulted from porous microstructure and roughness of the surface of the biomaterials (Figure 5a,b). Since the MC3T3-E1 cells formed clusters on the surface of the samples, quantitative evaluation of the cell spreading area was possible only for osteoblasts cultured in PS wells in the presence of the extracts.

Cells exhibited similar morphology when cultured in all extracts, however, osteoblasts cultured in the presence of chit/aga/HA-Mg extract revealed significantly higher $(P<0.0001)$ spreading area as compared to the cells maintained in other extracts and the control medium (Figure 5d), which was also confirmed by CLSM visualization (Figure $5 b$ ). However, such results were not observed for chit/aga/HA-Mg/Zn scaffold, although it contained $\mathrm{Mg}^{2+}$ ions in its structure. Nevertheless, it should be noted that chit/aga/HA-Mg/Zn was made of $15 \mathrm{wt} \% \mathrm{Mg}$-doped HA and $15 \mathrm{wt} \% \mathrm{Zn}$-doped HA, whereas, chit/aga/HA-Mg contained $30 \mathrm{wt} \% \mathrm{HA}-\mathrm{Mg}$. According to the available literature, Mg-doped bioceramics has been proven to support cell adhesion and spreading on the biomaterial surface, which is mediated by membrane-associated adhesion receptors, i.e., integrins. The extracellular domain of integrins contains motifs which bond divalent cations $\left(\mathrm{Mg}^{2+}\right.$ and $\left.\mathrm{Ca}^{2+}\right)$. The changes in extracellular concentration of these ions may alter the affinity of integrins to their respective ligands, and therefore affect cell adhesion [7].

\subsubsection{Cell Proliferation}

Studies have reported that certain concentrations of $\mathrm{Mg}^{2+}$ and $\mathrm{Zn}^{2+}$ ions act as positive stimuli, enhancing osteoblasts proliferation and osteogenic differentiation [6,24-26]. Thus, it has been observed that researchers more often modify implantable biomaterials with the above-mentioned metal ions in order to improve biocompatibility of the resultant material. 

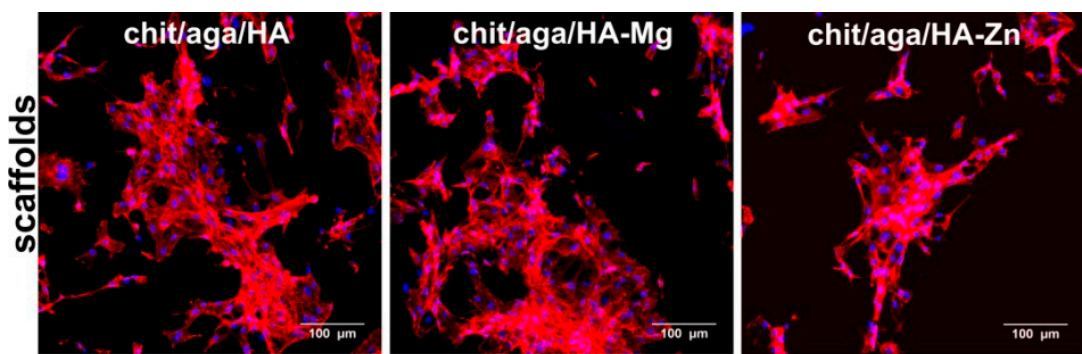

(a)
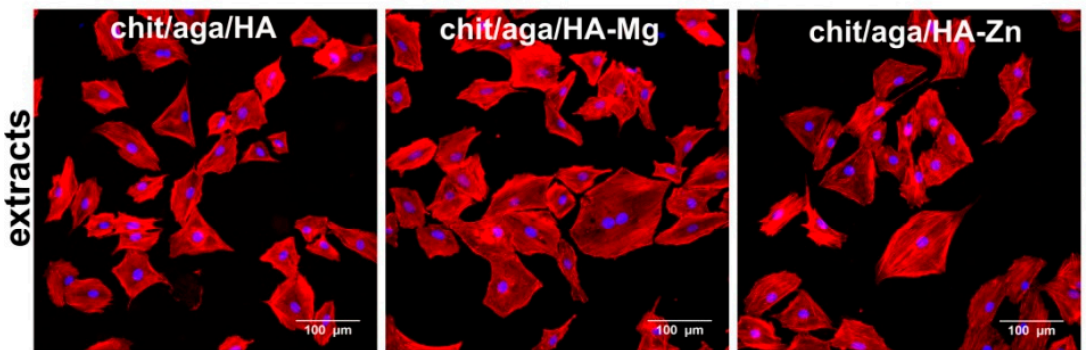

(b)

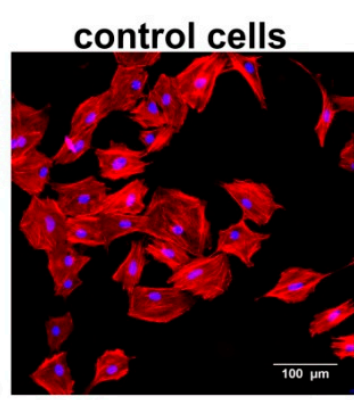

(c)

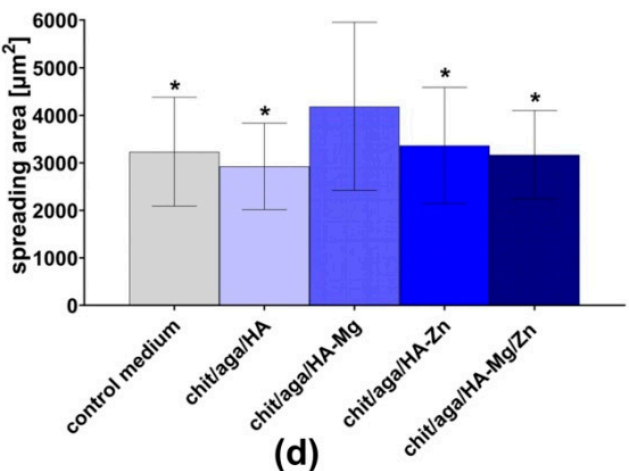

(d)
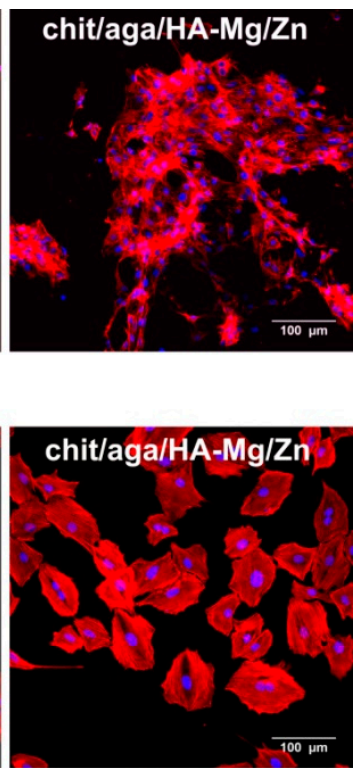

Figure 5. Evaluation of cell adhesion and spreading of MC3T3-E1 cells: (a) fluorescent staining of cell cytoskeleton when osteoblasts were cultured directly on the scaffolds; (b) fluorescent staining of cell cytoskeleton when osteoblasts were cultured in PS wells in the presence of scaffolds extracts (F-actin filaments, red fluorescence and nuclei, blue fluorescence, magnified 200×, scale bar $=100 \mu \mathrm{m}$ ); (c) morphology of control cells maintained in culture medium and grown in the polystyrene wells PS wells; and (d) quantitative evaluation of spreading area of cells cultured in the PS wells in the presence of scaffolds extracts (* statistically significant results as compared to chit/aga/HA-Mg extract, $P<0.05$, one-way ANOVA followed by Tukey's test).

In this study, osteoblasts proliferation was determined by evaluating the cell number on the surface of the biomaterials and in the PS wells upon exposure to the scaffold extracts after one, three, and six days of culture. Among all the fabricated samples, the biomaterials containing Mg-doped HA (chit/aga/HA-Mg and chit/aga/HA-Mg/Zn) were the most favorable to cell proliferation (Figure 6a). The MC3T3-E1 osteoblasts revealed significantly enhanced proliferation when cultured on these scaffolds as compared to the control material (chit/aga/HA). Importantly, the cells grown on the biomaterials containing HA-Mg revealed similar doubling time (DT) (i.e., defined as the period of time in hours required to double cell population) as compared to the control cells cultured in the PS well. Moreover, on the third day of the experiment, the number of cells on the surface of chit/aga/HA-Mg/Zn was significantly higher $(P=0.0372)$ as compared to the PS control. Interestingly, although $\mathrm{Zn}^{2+}$ was reported to enhance cell proliferation [27], incorporation of $\mathrm{Zn}^{2+}$ ions into the scaffold structure (chit/aga/HA-Zn) did not improve cell proliferation as compared to the control chit/aga/HA material. Thus, enhanced cell proliferation on the surface of the chit/aga/HA-Mg and chit/aga/HA-Mg/Zn scaffolds resulted from the presence of $\mathrm{Mg}^{2+}$ ions in their structure. 
Scaffolds

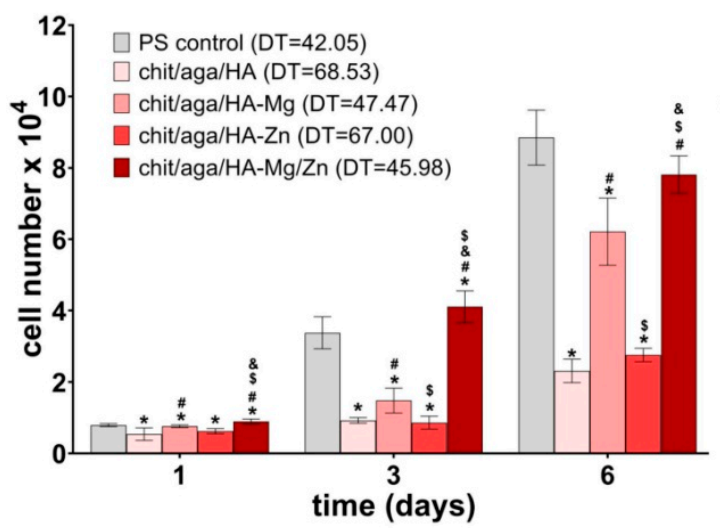

(a)
Extracts

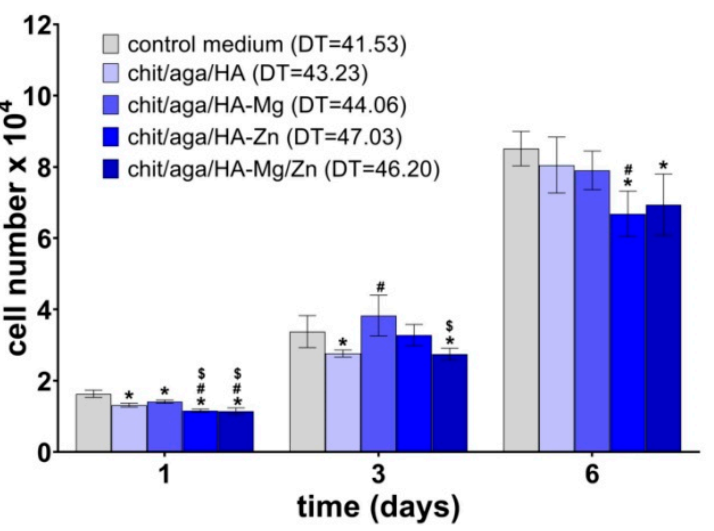

(b)

Figure 6. MC3T3-E1 cell proliferation analysis: (a) osteoblasts cultured on the surface of the scaffolds (PS control, cells cultured in the PS well of 96-multiwell plate) and (b) osteoblasts cultured in the PS wells in the presence of scaffolds extracts (control medium, cells maintained in culture medium). DT, doubling time in hours; * statistically significant results as compared to control; ${ }^{\#}$ statistically significant results as compared to chit/aga/HA; ${ }^{\$}$ statistically significant results as compared to chit/aga/HA-Mg; \& statistically significant results as compared to chit/aga/HA-Zn; $P<0.05$, one-way ANOVA followed by Tukey's test.

The experiment with the use of scaffold extracts showed negligible differences in cell proliferation between tested extracts of the materials (Figure 6b). Nevertheless, on the sixth day of the experiment, extracts of chit/aga/HA-Zn and chit/aga/HA-Mg/Zn significantly reduced the cell number as compared to the control cells maintained in the cultured medium. The DT values calculated for the MC3T3-E1 cells cultured in the presence of the extracts were comparable to the DT values recorded for the control cells. However, higher values of DT were observed for extracts containing Zn ions.

Observed divergent results that were obtained with direct contact and indirect experiments most likely resulted from various exposure times of scaffolds to the culture medium. The extraction process of the biomaterials lasted $24 \mathrm{~h}$, whereas, during direct contact test, the scaffolds were incubated in culture medium for six days which allowed higher concentrations of released ions to be achieved. Importantly, our results contradict reports presented by other authors based on the available literature, that both $\mathrm{Zn}^{2+}$ and $\mathrm{Mg}^{2+}$ ions have the ability to stimulate proliferation of the cells [6,27]. Yoshizawa et al. [6] demonstrated that $\mathrm{Mg}^{2+}$ ions enhance proliferation of BMDSCs and their osteogenic differentiation. Whereas, Moon et al. [28] revealed that $\mathrm{Zn}^{2+}$ increased adipose tissue-derived mesenchymal stem cells (ADSCs) proliferation via activation of the ERK1/2 pathway. Similarly, Ullah et al. [29] showed that the incorporation of zinc oxide into chitosan-collagen scaffolds supports fibroblasts and keratinocytes adhesion, proliferation, and infiltration of biomaterial.

\subsubsection{Evaluation of Osteogenic Differentiation}

Mesenchymal stem cells (MSCs) derived from bone marrow or adipose tissue are excellent biological sources of osteoprogenitor cells for bone tissue engineering applications. Detection of osteogenic differentiation markers in MSCs cultured on the surface of the biomaterial is undoubtedly proof of osteoconductive or osteoinductive (if the cells are cultured without osteogenic inducers) properties of the tested scaffold. During osteogenic differentiation, osteoprogenitor cells/osteoblasts produce several specialized proteins, which are considered as markers of the bone formation process. The differentiation process involves the following three main stages: (1) proliferation phase when the cells proliferate intensively and produce great amounts of Col I and fibronectin; (2) ECM synthesis phase when the cells reveal the highest bALP activity and intensively produce proteins of bone ECM; and (3) 
ECM mineralization phase when the cells exhibit moderate bALP production, high mineralization activity, and produce significant amounts of OC and osteopontin [30,31].

In this study, the level of typical osteogenic markers (bALP, Col I, and OC) produced by MCSs grown on the surface of the biomaterials and in PS wells upon exposure to the scaffolds extracts was evaluated after 21 day culture. It was observed that BMDSCs and ADSCs cultured on the chit/aga/HA surface produced significantly higher amounts of bALP, Col I, and OC as compared to the cells cultured on other scaffolds (Figure 7a). Interestingly, MSCs cultured on the biomaterial containing Zn-doped HA (chit/aga/HA-Zn and chit/aga/HA-Mg/Zn) showed higher levels of bALP and Col I than that of cells cultured on the chit/aga/HA-Mg. Nevertheless, BMDSCs cultured on the chit/aga/HA-Mg showed higher OC synthesis as compared to chit/aga/HA-Zn and chit/aga/HA-Mg/Zn. Importantly, MSCs cultured on the surface of the scaffolds containing Mg-doped HA and Zn-doped HA did not exhibit enhanced synthesis of osteogenic markers as compared to the cells grown on biomaterial made of pure HA. Thus, the results of this study are not consistent with the information found in the available literature which reports an increased production of osteogenic markers by MSCs in the presence $\mathrm{Mg}^{2+}$ and $\mathrm{Zn}^{2+}$ ions [10,24-26,28,32]. However, it should be noted that differentiation of MSCs cultured on the surface of biomaterials may be affected by various factors such as chemical composition of the scaffolds, porosity, surface roughness [30,33], and even stiffness (Young's modulus) of the materials [34,35]. It is well known that calcium phosphate-based materials with highly macroporous structures and rough surfaces may have the ability to induce osteogenic differentiation in MSCs [30]. Moreover, it has been demonstrated that cells cultured on substrates with low stiffness show enhanced osteogenic differentiation [35]. The scaffolds produced in this study that were made of calcium phosphate ceramics (nanoHA), showed high elasticity (low stiffness), and had a highly macroporous and rough structure (Figure 3). Therefore, the MSC differentiation observed on the surface of the investigated bone scaffolds was not only affected by $\mathrm{Mg}^{2+}$ and $\mathrm{Zn}^{2+}$ ions, but it was also a result of the microstructural, mechanical, and physicochemical properties of the materials. This may explain the discrepancy between the results obtained here and the results presented by other authors who performed studies on scaffolds having different chemical compositions and microstructural properties. Other factors which most likely influenced our results, as compared to other authors, were the divergent degree of ceramic substitution with $\mathrm{Mg}^{2+}$ and $\mathrm{Zn}^{2+}$ and the different release rates of these ions from the biomaterials.

In the case of the indirect test with the use of extracts of the scaffolds, osteogenic markers were detected by the enzyme-linked immunosorbent assays (ELISAs), and also by the immunofluorescent (IF) staining of Col I and OC, as well as by Alizarin Red S staining (ARS) of mineral deposited in ECM. The BMDSCs cultured in the control medium revealed significantly higher $(P<0.0001$ as compared to the extracts of chit/aga/HA-Mg, chit/aga/HA-Zn, and chit/aga/HA-Mg/Zn; $P=0.0144$ as compared to chit/aga/HA extract) bALP production as compared to the cells maintained in the extracts of the scaffolds. The very high level of bALP in the BMDSCs maintained in the control medium along with the decreased OC production (Figures $7 \mathrm{~b}$ and 8 ) and poor mineralization activity (Figure 9) may suggest that on the twenty-first day of the experiment these cells were still in the second stage of osteogenic differentiation (ECM synthesis). On the other hand, the BMDSCs exposed to the extracts of chit/aga/HA-Mg and chit/aga/HA-Mg/Zn scaffolds showed significantly reduced production of bALP, increased synthesis of OC which was also confirmed by IF staining (Figures $7 \mathrm{~b}$ and 8), and poor mineralization activity (Figure 9). Thus, despite a high amount of OC (protein which is related to ECM calcification [31]) in the ECM of BMDSCs, the mineralization process did not begin. These observations indicate that the biomaterial containing $\mathrm{Mg}^{2+}$ ions caused a significant reduction in bALP synthesis (enzyme essential for mineralization process [31]), delaying the third stage of osteogenic differentiation and ECM calcification. Interestingly, the BMDSCs cultured in the presence of the chit/aga/HA extract revealed a moderate level of bALP which is typical of the third stage of osteogenic differentiation. As a consequence, ARS staining demonstrated the highest mineralization activity of these cells (Figure 9). The positive impact of scaffold extracts (especially chit/aga/HA extract) on ECM mineralization (Figure 9) can be explained by the dissolution of the bioceramics and the 
stimulation of HA deposition by released $\left(\mathrm{Ca}^{2+}\right)$ and phosphate $\left(\mathrm{PO}_{4}{ }^{3-}\right)$ ions, which play an essential role in bone metabolism. $\mathrm{Ca}^{2+}$ is known to support osteoblast adhesion, proliferation, differentiation, and ECM mineralization. Moreover, it stimulates Ca-sensing receptors in osteoblasts and enhances expression of insulin-like growth factors, e.g., IGF-1 and IGF-2 [4,36]. Whereas, $\mathrm{PO}_{4}{ }^{3-}$ regulates cell proliferation and stimulates the expression of matrix Gla protein (MGP) and ECM mineralization by increasing IGF-1 synthesis $[4,36,37]$.
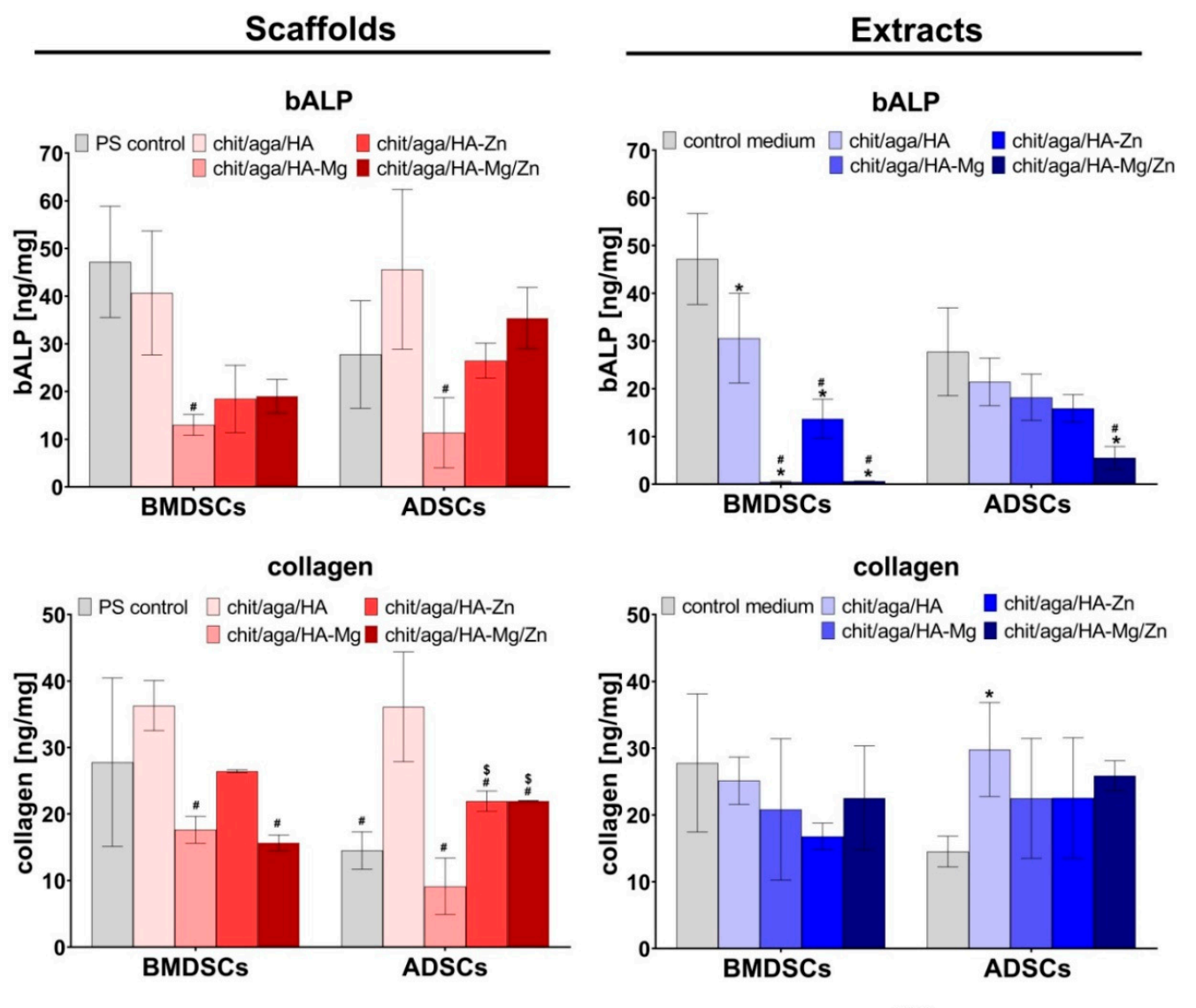

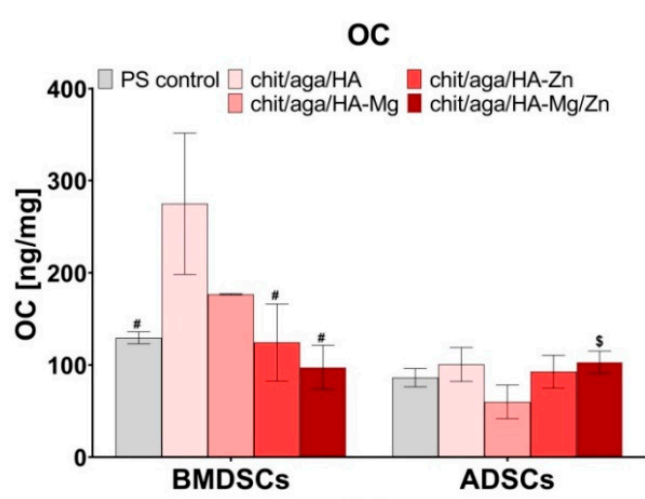

(a)

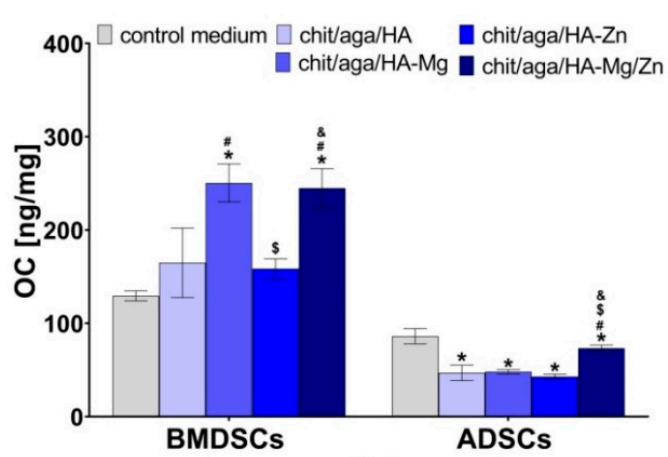

(b)

Figure 7. The level of osteogenic markers assessed by enzyme-linked immunosorbent assay (ELISAs): (a) level of markers in mesenchymal stem cells (MSCs) grown on the scaffolds (PS control, cells cultured in PS wells); (b) level of markers in MSCs cultured in PS wells in the presence of scaffolds extracts (control medium, cells maintained in osteogenic medium). The results were expressed as ng of marker per mg of total cellular proteins. * statistically significant results as compared to PS control/control

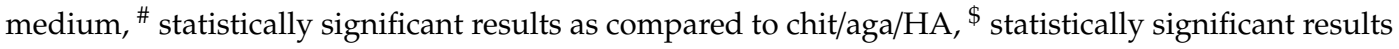
as compared to chit/aga/HA-Mg, \& statistically significant results as compared to chit/aga/HA-Zn, $P<0.05$, one-way ANOVA followed by Tukey's test. 


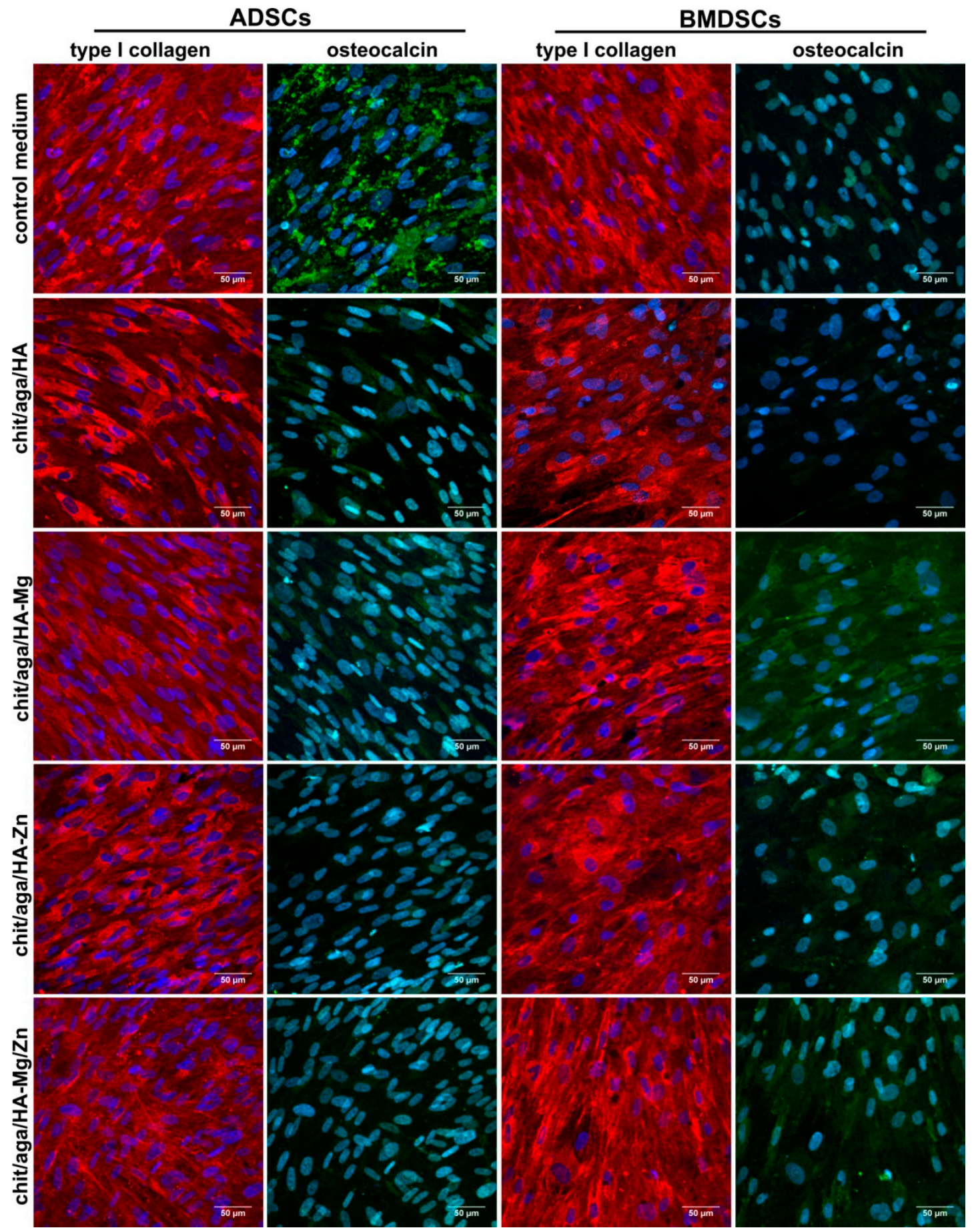

Figure 8. CLSM images presenting immunofluorescent (IF) staining of type I collagen and osteocalcin in the extracellular matrix (ECM) of MSCs cultured in PS wells in the presence of scaffolds extracts (control medium, cells maintained in osteogenic medium); collagen, red fluorescence; osteocalcin, green fluorescence; and nuclei, blue fluorescence, magnified 400x; scale bar $=50 \mu \mathrm{m}$. 


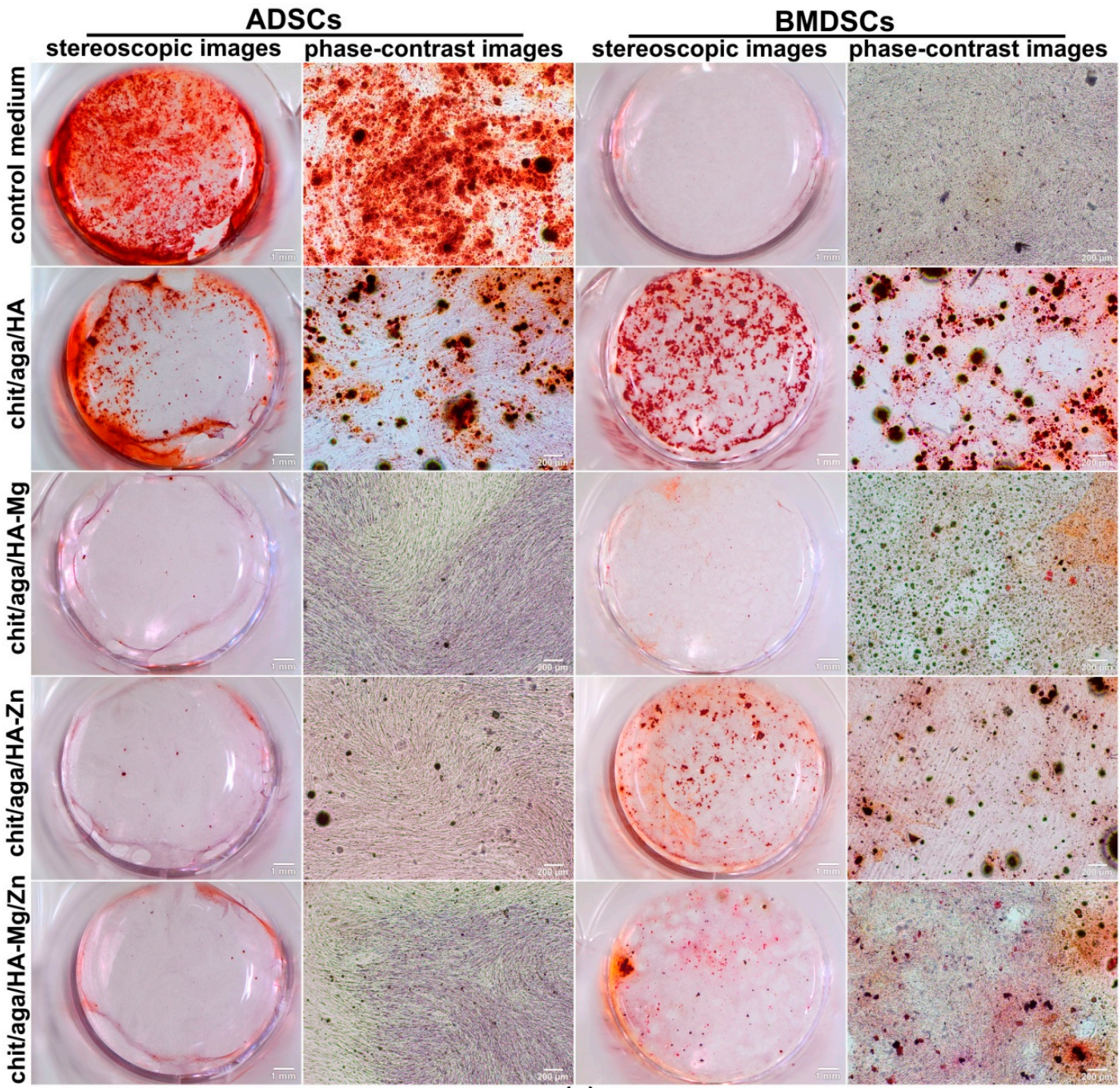

(a)

ADSCs

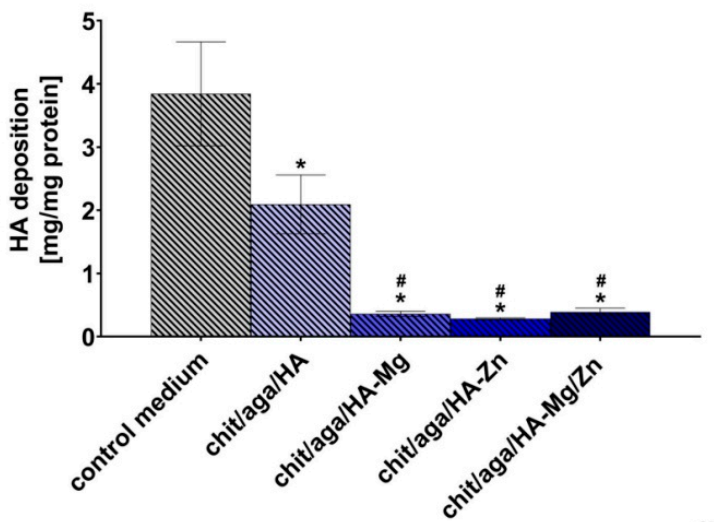

(b)

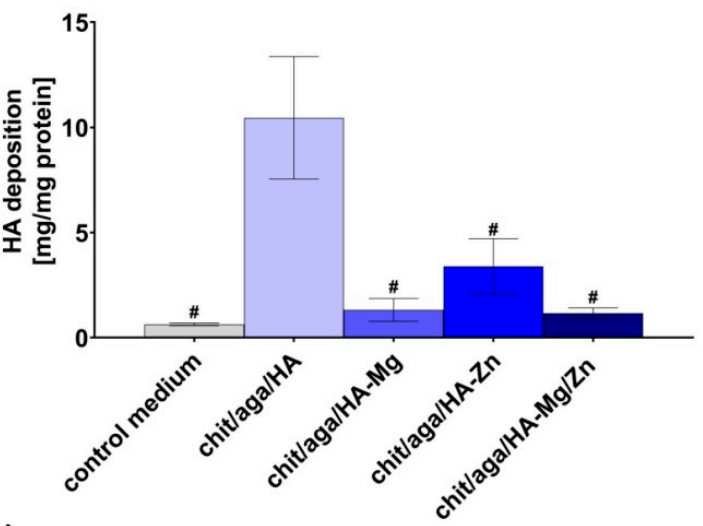

Figure 9. Evaluation of mineral deposition in ECM of MSCs cultured in PS wells in the presence of scaffolds extracts (control medium, cells maintained in osteogenic medium): (a) stereoscopic and phase-contrast images presenting ARS staining of bone marrow-derived stem cells (BMDSCs) and adipose tissue-derived mesenchymal stem cells (ADSCs) (stereoscopic images, scale bar = $1 \mathrm{~mm}$ and 
phase-contrast images, scale bar $=200 \mu \mathrm{m})$; $(\mathbf{b})$ quantitative evaluation of mineral deposits in ECM of MSCs. The mineral deposition was expressed as $\mathrm{mg}$ of mineral per $\mathrm{mg}$ of total cellular proteins. * statistically significant results as compared to control medium, ${ }^{\#}$ statistically significant results as compared to chit/aga/HA, $P<0.05$, one-way ANOVA followed by Tukey's test.

In the case of ADSCs, all extracts of the biomaterials decreased bALP and OC synthesis, but increased Col I production as compared to the control cells maintained in the osteogenic medium (Figure 7b). Interestingly, the ADSCs maintained in the extracts of the scaffolds containing $\mathrm{Mg}^{2+}$ and/or $\mathrm{Zn}^{2+}$ ions showed significantly reduced mineralization activity as compared to the control cells and also as compared to the chit/aga/HA extract (Figure 9). The reduced level of bALP and OC, along with poor ECM calcification, suggests that ADSCs cultured in the extracts containing $\mathrm{Mg}^{2+}$ and/or $\mathrm{Zn}^{2+}$ were still in the first stage of osteogenic differentiation. Unlike cells exposed to the scaffold extracts, the ADSCs cultured in the control medium showed a moderate bALP level (Figure 7b), high OC production, and high mineralization activity (Figures 8 and 9), and therefore they were in the third phase of osteogenic differentiation.

The results of this study demonstrated that the incorporation of $\mathrm{Mg}^{2+}$ and $\mathrm{Zn}^{2+}$ metal ions in the structure of the chit/aga/HA scaffold retard osteogenic differentiation of MSCs because stem cells cultured on the biomaterial made of pure HA or in the chit/aga/HA extract showed a higher level of osteogenic markers and higher mineralization activity as compared to other scaffolds. Therefore, modification of chit/aga/HA biomaterial with metal ions did not produce the expected results despite numerous reports about the positive impact of $\mathrm{Mg}^{2+}$ and $\mathrm{Zn}^{2+}$ ions on the bone formation process. Jin et al. [32] revealed that $\mathrm{Zn}^{2+}$ ions stimulated bALP activity, collagen secretion, and ECM mineralization in rat MSCs. Kim et al. showed that extract containing $\mathrm{Mg}^{2+}$ increased bALP activity and ECM mineralization in hFOB 1.19 cells [38]. Whereas, Thian et al. demonstrated enhanced proliferation and differentiation of ADSCs cultured on biomaterial made of Zn-doped HA [27].

Nevertheless, the literature has reported other biological activities of metal ions such as the improvement of cell adhesion, spreading, and proliferation, which were also found in our results. This study demonstrated that the incorporation of $\mathrm{Mg}^{2+}$ ions in the chit/aga/HA structure increased the spreading of the osteoblasts and promoted cell proliferation on the scaffold surface. Importantly, although, in general, $\mathrm{Mg}^{2+}$ ions retarded osteogenic differentiation of MSCs, the presence of $\mathrm{Mg}^{2+}$ in the extracts of biomaterials enhanced osteocalcin production by BMDSCS as compared to the chit/aga/HA extract and the control medium. Surprisingly, $\mathrm{Zn}^{2+}$ incorporation into the chit/aga/HA scaffold did not improve cell spreading and proliferation, but MSCs cultured on the scaffolds or in extracts containing $\mathrm{Zn}^{2+}$ showed enhanced Col I production and extracellular matrix mineralization as compared to the cells cultured in the PS well. However, biomaterial made of pure HA gave better results than material with $\mathrm{Zn}^{2+}$ incorporation.

In conclusion, the results of this study showed that modification of chit/aga/HA scaffold with $\mathrm{Zn}^{2+}$ does not have any positive impact on cell behavior, whereas, incorporation of $\mathrm{Mg}^{2+}$ ions in its structure may significantly improve the biocompatibility of the resultant material, increasing its potential in biomedical applications. Interestingly, contrary to the common opinion that hydroxyapatite substituted with Zn ions may significantly improve cell proliferation and differentiation, we showed that Zn-doped HA was less efficient than Mg-doped HA and even worsened the biocompatibility of the resulting bioceramic-based material as compared to the scaffold containing pure HA. Thus, our results provide new insight into the use of $\mathrm{Zn}$ ions for scaffold modifications in the engineering of biomaterials.

\section{Materials and Methods}

\subsection{Synthesis and Characterization of NanoHA}

The synthesis of three nanopowders: undoped, $\mathrm{Mg}$, and $\mathrm{Zn}$ which contained hydroxyapatite (HA, HA-Mg, and HA-Zn) were prepared according to the wet precipitation method. Calcium nitrate tetrahydrate $\left(\mathrm{Ca}\left(\mathrm{NO}_{3}\right)_{2} \cdot 4 \mathrm{H}_{2} \mathrm{O}\right)$, diammonium hydrogen phosphate $\left(\left(\mathrm{NH}_{4}\right)_{2} \mathrm{HPO}_{4}\right)$, zinc nitrate 
hexahydrate $\left(\mathrm{Mg}\left(\mathrm{NO}_{3}\right)_{2} \cdot 6 \mathrm{H}_{2} \mathrm{O}\right)$ and magnesium nitrate hexahydrate $\left(\mathrm{Zn}\left(\mathrm{NO}_{3}\right)_{2} \cdot 6 \mathrm{H}_{2} \mathrm{O}\right)$ were purchased from Sigma-Aldrich Chemicals (Warsaw, Poland) and used as sources of calcium, phosphorus, magnesium, and zinc, respectively. The expected doping levels for $\mathrm{Mg}^{2+}$ or $\mathrm{Zn}^{2+}$ were $0.03 \mathrm{~mol}$ for 1 mol of HA-Mg or HA-Zn powder, respectively. The aqueous solutions of the precursors were prepared in such a way that the $\mathrm{Ca} / \mathrm{P}$ in $\mathrm{HA},(\mathrm{Ca}+\mathrm{Mg}) / \mathrm{P}$ in $\mathrm{HA}-\mathrm{Mg}$, and $(\mathrm{Ca}+\mathrm{Zn}) / \mathrm{P}$ in $\mathrm{HA}-\mathrm{Zn}$ molar ratio was equal to 1.67 . The powders were obtained via a standard precipitation method by slowly adding an aqueous solution of $\left(\mathrm{NH}_{4}\right)_{2} \mathrm{HPO}_{4}$, to mixed aqueous solutions of $\mathrm{Ca}\left(\mathrm{NO}_{3}\right)_{2} \cdot 4 \mathrm{H}_{2} \mathrm{O}$ (and $\mathrm{Mg}\left(\mathrm{NO}_{3}\right)_{2} \cdot 6 \mathrm{H}_{2} \mathrm{O}$ or $\left.\mathrm{Zn}\left(\mathrm{NO}_{3}\right)_{2} \cdot 6 \mathrm{H}_{2} \mathrm{O}\right)$ under vigorous stirring. The $\mathrm{pH}$ of the mixtures was maintained at 9 by adding ammonia solution (Avantor Performance Materials, Gliwice, Poland). The obtained suspensions were heated at $70{ }^{\circ} \mathrm{C}$ for $2 \mathrm{~h}$ and then kept in static conditions for aging. After $24 \mathrm{~h}$, the precipitates were filtered, washed several times, and dried at $100{ }^{\circ} \mathrm{C}$. Then, the powders were calcined at $1000^{\circ} \mathrm{C}$ for $1 \mathrm{~h}$.

The produced nanoHA powders were subjected to structural and physicochemical analysis to determine the $\mathrm{Zn}$ or $\mathrm{Mg}$ content, crystallinity, and the size and shape of the particles. Transmission electron microscope (TEM) (JEM 1400, Jeol Co., Tokyo, Japan) studies were carried out at an accelerating voltage of $80 \mathrm{kV}$. The analyzed powders were prepared by dispersing a sample in $96^{\circ}$ ethanol, followed by dropping it into a copper grid covered with Formvar film, and air drying. Elemental analysis of the doped cations $\left(\mathrm{Mg}^{2+}\right.$ and $\left.\mathrm{Zn}^{2+}\right)$ were performed using inductively coupled plasma spectrometry (ICP-OES, Thermo Scientific iCAP 7400 Duo, Waltham, MA, USA). For this purpose, the powders were dissolved in supra pure 63\% nitric acid (Sigma-Aldrich Chemicals, Warsaw, Poland) and deionized water. The PXRD patterns were recorded on a Bruker DX8 Discover diffractometer (CuK $\alpha$ radiation, $\lambda=1.54 \AA$ ) and registered in the 2-theta range within $20^{\circ}$ to $60^{\circ}$. Both $a$ and $c$ lattice parameters of the unit cell were obtained from the TOPAS program. The software uses Rietveld refinement based on analytical profile functions and least squares algorithms to fit a theoretical to a measured PXRD. Moreover, the software uses Scherrer formula for crystallite size calculation. The FT-IR transmission spectra were collected in the range of $4000-400 \mathrm{~cm}^{-1}$, at room temperature on a Perkin Elmer Spectrum 1000 spectrometer with a resolution of $2 \mathrm{~cm}^{-1}$ and 30 scans.

\subsection{Fabrication of the Scaffolds}

Four types of chitosan-agarose-hydroxyapatite scaffolds containing $30 \mathrm{wt} \%$ pure HA (control sample marked as chit/aga/HA), $30 \mathrm{wt} \% \mathrm{Mg}$-doped HA (marked as chit/aga/HA-Mg), $30 \mathrm{wt} \% \mathrm{Zn}$-doped HA (marked as chit/aga/HA-Zn), and mixture of $15 \mathrm{wt} \% \mathrm{Mg}$-doped HA and $15 \mathrm{wt} \% \mathrm{Zn}$-doped HA (marked as chit/aga/HA-Mg/Zn) were synthesized in accordance with the procedure described in the Polish patent application no. P.426788. The scaffolds were produced by a combination of gas-foaming and freeze-drying methods. In brief, composites were prepared by mixing suspension of $2 \mathrm{wt} \%$ chitosan (50-190 kDa molecular weight, 75\%-85\% deacetylation degree, viscosity $\leq 300 \mathrm{cP}$, Sigma-Aldrich Chemicals, Warsaw, Poland) and $5 \mathrm{wt} \%$ agarose (low EEO, gel point $36 \pm 1.5^{\circ} \mathrm{C}$, Sigma-Aldrich Chemicals) in $2 \%$ acetic acid solution (Avantor Performance Materials, Gliwice, Poland) with the appropriate type of $\mathrm{HA}$ and sodium bicarbonate $\left(\mathrm{NaHCO}_{3}\right.$, Sigma-Aldrich Chemicals, Warsaw, Poland) added as a foaming agent. The obtained paste was put in a cylinder-shaped vial, then heated in a water bath at a temperature of $95^{\circ} \mathrm{C}$, cooled, frozen in a liquid nitrogen vapor phase, and subjected to freeze drying (LYO GT2-Basic, SRK Systemtechnik GmbH, Riedstadt, Germany). The final samples were neutralized in $1 \%$ sodium hydroxide solution $(\mathrm{NaOH}$, Avantor Performance Materials, Gliwice, Poland), rinsed with deionized water, and left to air dry. The microstructure of the produced scaffolds was visualized by a stereoscopic microscope (Olympus SZ61TR, Olympus Polska Sp. z o. o., Warsaw, Poland). Prior to all experiments, the samples were sterilized by ethylene oxide. Before the cell culture experiments, the samples were preincubated overnight in appropriate complete culture medium at $37^{\circ} \mathrm{C}$. 


\subsection{Preparation of Scaffolds Extracts}

Extracts of the scaffolds were prepared in accordance with ISO 10993-12 standard. Briefly, the sterile scaffolds were immersed in an appropriate complete culture medium (maintaining the ratio of $100 \mathrm{mg}$ sample per $1 \mathrm{~mL}$ medium) and incubated at $37^{\circ} \mathrm{C}$ for $24 \mathrm{~h}$. The culture medium incubated without scaffolds served as the control (marked as control). The $\mathrm{Mg}^{2+}$ and $\mathrm{Zn}^{2+}$ ions concentrations in the collected extracts were evaluated by colorimetric method using commercially available kits for the determination of magnesium (BioMaxima, Lublin, Poland) and zinc ions (Sigma-Aldrich Chemicals, Warsaw, Poland). The prepared extracts were subjected to in vitro cell culture experiments.

\subsection{In Vitro Cell Culture Experiments}

Mouse calvarial preosteoblast cell line (MC3T3-E1 Subclone 4, ATCC-LGC standards, Teddington, UK), human bone marrow-derived mesenchymal stem cells (BMDSCs, ATCC-LGC standards, Teddington, UK), and human adipose tissue-derived mesenchymal stem cells (ADSCs, ATCC-LGC standards, Teddington, UK) were used in the experiments. The MC3T3-E1 cells were cultured in an alpha-MEM medium (Gibco, Life Technologies, Carlsbad, CA, USA) containing $10 \%$ fetal bovine serum (FBS, Pan-Biotech $\mathrm{GmbH}$, Aidenbach, Bavaria, Germany), $100 \mathrm{U} / \mathrm{mL}$ penicillin, $100 \mu \mathrm{g} / \mathrm{mL}$ streptomycin (Sigma-Aldrich Chemicals, Warsaw, Poland). The BMDSCs were cultured in Mesenchymal Stem Cell Basal Medium (ATCC-LGC Standards, Teddington, UK) supplemented with the components of Bone Marrow-Mesenchymal Stem Cell Growth Kit (ATCC-LGC Standards, Teddington, UK), and antibiotics: $10 \mathrm{U} / \mathrm{mL}$ penicillin and $10 \mu \mathrm{g} / \mathrm{mL}$ streptomycin. The ADSCs were cultured in Mesenchymal Stem Cell Basal Medium supplemented with the components of Adipose-derived Mesenchymal Stem Cell Growth Kit Low Serum (ATCC-LGC Standards, Teddington, UK), and antibiotics: $10 \mathrm{U} / \mathrm{mL}$ penicillin and $10 \mu \mathrm{g} / \mathrm{mL}$ streptomycin. All cells were incubated at $37^{\circ} \mathrm{C}$ in a humidified atmosphere of $5 \% \mathrm{CO}_{2}$ in air atmosphere.

\subsubsection{Cytotoxicity Assessment}

Cytotoxicity assessment was carried out according to ISO 10993-5 standard by indirect method using $24 \mathrm{~h}$ extracts of the samples prepared as described in Section 3.3. The MC3T3-E1 cells were seeded into 96-multiwell plate in $100 \mu \mathrm{L}$ of a complete culture medium at a concentration of $2 \times 10^{4}$ cells per well. After $24 \mathrm{~h}$ incubation, the culture medium was discarded, and appropriate scaffolds extracts were added. Culture medium served as a negative control of cytotoxicity. After 24 and $48 \mathrm{~h}$, MTT (Sigma-Aldrich Chemical, Warsaw, Poland) colorimetric assay was performed to evaluate cell viability as described previously [39]. The results of the MTT assay were expressed as the percentage of absorbance value obtained with the negative control.

Cytotoxicity assessment in direct contact of osteoblasts with the scaffolds was performed by live-dead double fluorescent staining. The MC3T3-E1 cells were seeded directly on the scaffold discs ( $2 \mathrm{~mm}$ thick and $8 \mathrm{~mm}$ in diameter) in $500 \mu \mathrm{L}$ of a complete culture medium at a density of $3 \times 10^{5}$ cells $/ \mathrm{mL}$. After $48 \mathrm{~h}$ of culture, osteoblasts were stained with Live-Dead Double Staining Kit (Sigma-Aldrich Chemical, Warsaw, Poland) in accordance with the manufacturer's procedure. The kit is comprised of calcein-AM dye and propidium iodide dye, which stains viable and dead cells, respectively. Stained cells were observed using a confocal laser scanning microscope (CLSM, Olympus Fluoview equipped with FV1000, Olympus Polska Sp. z o. o., Warsaw, Poland).

\subsubsection{Cell Adhesion, Spreading, and Proliferation Assessment}

Evaluation of cell adhesion, spreading, and proliferation was carried out by seeding MC3T3-1 cells directly on the scaffolds as well as by culturing the osteoblasts in 96-multiwell plate in $24 \mathrm{~h}$ extracts of the samples, prepared as described in Section 3.3. The MC3T3-E1 cells were seeded directly on the scaffold discs ( $2 \mathrm{~mm}$ thick and $5 \mathrm{~mm}$ in diameter) placed in the wells of 96-multiwell plate and in the PS wells of 96-multiwell plate in $100 \mu \mathrm{L}$ of complete culture medium at a density of 
$8 \times 10^{4}$ cells $/ \mathrm{mL}$. After $24 \mathrm{~h}$ culture of osteoblasts in PS wells, the culture medium was replaced with appropriate extracts. In the case of cell adhesion and the spreading experiment, on the second day, the cells were fixed with 3.7\% (v/v) paraformaldehyde (Sigma-Aldrich Chemicals, Warsaw, Poland) for $10 \mathrm{~min}$, permeabilized with $0.2 \%(v / v)$ Triton X-100 (Sigma-Aldrich Chemicals, Warsaw, Poland) for $20 \mathrm{~min}$, and blocked with $1 \%(w / v)$ bovine serum albumin (BSA, Sigma-Aldrich Chemicals, Warsaw, Poland) for $30 \mathrm{~min}$. Then, the cytoskeleton filaments were stained for $30 \mathrm{~min}$ at room temperature with AlexaFluor635-conjugated phallotoxin (Invitrogen, Carlsbad, California, USA). Counterstaining was conducted using $0.5 \mu \mathrm{g} / \mathrm{mL}$ DAPI (Sigma-Aldrich Chemicals, Warsaw, Poland). Stained cells were observed using CLSM. Spreading area of at least 80 individual cells was measured using ImageJ software version 1.52a (Wayne Rasband, National Institutes of Health, Bethesda, Maryland, USA)

The cell proliferation test was carried out for 6 days. Every second day of the experiment, half of the culture medium or appropriate extract was replaced with a fresh portion. On the first, third, and sixth day, osteoblasts were lysed, and the total cell number was determined based on the Lactate Dehydrogenase Activity Assay Kit (Sigma-Aldrich Chemicals, Warsaw, Poland) in accordance with the manufacturer's protocol. The cell number was calculated from the calibration curve made for known concentrations of MC3T3-E1 cells. The doubling time for the cells was calculated using Doubling Time Computing software version 3.1.0.

\subsubsection{Evaluation of Osteogenic Differentiation}

Evaluation of osteogenic differentiation was carried out by seeding mesenchymal stem cells directly on the scaffolds, as well as by culturing the cells in 96-multiwell plate in $24 \mathrm{~h}$ extracts of the samples, prepared as described in Section 3.3 but using osteogenic medium (Osteocyte Differentiation Tool, ATCC-LGC standards, Teddington, UK). The BMDSCs and ADSCs were seeded directly on the scaffold discs ( $2 \mathrm{~mm}$ thick and $8 \mathrm{~mm}$ in diameter) placed in the wells of 48 -multiwell plate and in the PS wells of 48 -multiwell plate in $500 \mu \mathrm{L}$ of complete culture medium at a density $2 \times 10^{5}$ cells $/ \mathrm{mL}$. After $24 \mathrm{~h}$ culture of the cells, osteogenic differentiation of the BMDSCs and ADSCs were induced by replacing the culture medium with osteogenic medium or appropriate extracts of the samples (prepared in osteogenic medium). Every third day, half of the medium/extract was replaced with a fresh portion. On the twenty-first day of the study, markers of the osteogenic differentiation (Col I, bALP and OC) were quantitatively evaluated in the cell lysates prepared as previously reported [40]. The Col I, bALP, and OC levels were measured using human-specific ELISA kits (Human Collagen alpha-1(I) chain ELISA Kit, EIAab, Wuhan, China; Human Bone Alkaline Phosphatase ELISA Kit, FineTest, Wuhan, China; Human Osteocalcin ELISA Kit, EIAab, Wuhan, China). The level of osteogenic markers was normalized to the total protein content, which was determined for each sample/well using a BCA Protein Assay Kit (Thermo Fisher Scientific, Waltham, Massachusetts, USA). The ELISA results were expressed as ng of osteogenic marker (Col I, bALP and OC) per mg of total cellular proteins.

In the case of cells cultured in the PS wells in the presence of the extracts, osteogenic differentiation was also visualized by IF staining of $\mathrm{Col} I$ and OC and by ARS staining of mineral deposited in ECM. For IF, the samples were fixed and permeabilized as described in Section 3.4.2. Then, the samples were incubated overnight at $4{ }^{\circ} \mathrm{C}$ with primary goat anticollagen I (Col1a1/Col1a2) polyclonal antibody (Abnova, Taoyuan City, Taiwan) and primary mouse anti-osteocalcin monoclonal antibody (Abcam, Cambridge, UK) prepared at a concentration of $10 \mu \mathrm{g} / \mathrm{mL}$. Subsequently, the samples were washed with PBS and incubated for $1 \mathrm{~h}$ at room temperature with secondary Alexa-Fluor ${ }^{\circledR} 647$ donkey anti-goat IgG $(\mathrm{H}+\mathrm{L})$ antibody (Abcam, Cambridge, UK) and secondary Alexa-Fluor ${ }^{\circledR} 488$ donkey anti-mouse IgG $(\mathrm{H}+\mathrm{L})$ antibody (Abcam, Cambridge, UK) was prepared at a concentration of $2 \mu \mathrm{g} / \mathrm{mL}$. Additionally, the cell nuclei were counterstained with the $0.5 \mu \mathrm{g} / \mathrm{mL}$ DAPI solution. Stained cells were visualized using CLSM. After IF staining of Col I and OC, the same samples were stained for $15 \mathrm{~min}$ at $37^{\circ} \mathrm{C}$ with $2 \%(w / v)$ alizarin red solution (Sigma-Aldrich Chemicals, Warsaw, Poland) prepared in deionized water. Then, the staining solution was removed, and the cells were rinsed 10 times with PBS without calcium and magnesium ions. The mineral deposits in ECM were visualized by a stereoscopic and phase-contrast 
microscope (Olympus CKX53, Olympus Polska Sp. z o. o., Warsaw, Poland). Afterwards, the same samples were subjected to quantitative analysis to determine the exact concentrations of deposited mineral. Briefly, $200 \mu \mathrm{L}$ of $10 \%$ acetic acid (Sigma-Aldrich Chemicals, Warsaw, Poland) were added to each well for $30 \mathrm{~min}$ in order to desorb calcium-bound ARS. Next, the cells were scraped from the plate and subjected to heating for $10 \mathrm{~min}$ at $85^{\circ} \mathrm{C}$. The cooled samples were centrifuged and $75 \mu \mathrm{L}$ of $10 \%$ ammonium hydroxide (Avantor Performance Materials, Gliwice, Poland) were added to the supernatants to neutralize the $\mathrm{pH}$. The OD values were detected at $405 \mathrm{~nm}$ (BioTek Synergy H4 Hybrid Microplate Reader, Winooski, Vermont, USA). Accurate amounts of deposited HA mineral were calculated from the calibration curve prepared for known concentrations of HA. Mineral deposition was normalized to total protein content and expressed as $\mathrm{mg}$ of mineral per $\mathrm{mg}$ of total cellular proteins. Unfortunately, quantification of mineral in the cells cultured directly on the scaffolds was impossible because the HA-based samples had the ability to bind ARS dye.

\subsection{Statistical Analysis}

All experiments were performed at least in triplicate $(n=3)$. The results were presented as mean values \pm standard deviation (SD). Statistically significant differences among all groups (control and various scaffolds) (considered at $P<0.05$ ) were determined by one-way ANOVA followed by Tukey's test (GraphPad Prism 8.0.0 Software).

\section{Patents}

The method for the production of the scaffolds was claimed in the Polish patent application no P.426788.

Author Contributions: Conceptualization, A.P.; methodology, A.P., P.K., and J.K.; formal analysis, P.K.; investigation, P.K. and J.K.; resources, A.P.; data curation, P.K. and J.K.; writing—original draft preparation, P.K.; writing - review and editing, A.P. and J.K.; visualization, A.P. and P.K.; supervision, A.P.; project administration, A.P.; and funding acquisition, A.P.

Funding: This research and APC was funded by the National Science Centre $(\mathrm{NCN})$ in Poland within OPUS 16 grant no. UMO-2018/31/B/ST8/00945. The paper was developed using the equipment purchased within agreement no. POPW.01.03.00-06-010/09-00 Operational Program Development of Eastern Poland 2007-2013, Priority Axis I, Modern Economy, Operations 1.3. Innovations Promotion.

Acknowledgments: The authors would like to thank Michal Wojcik from the Chair and Department of Biochemistry and Biotechnology of the Medical University of Lublin (Poland) for help with the confocal microscope analysis.

Conflicts of Interest: The authors declare no conflict of interest.

\section{Abbreviations}

$\begin{array}{ll}\text { ADSCs } & \text { Adipose tissue-derived mesenchymal stem cells } \\ \text { bALP } & \text { Bone alkaline phosphatase } \\ \text { BMDSCs } & \text { Human bone marrow-derived stem cells } \\ \text { BSA } & \text { Bovine serum albumin } \\ \text { CLSM } & \text { Confocal laser scanning microscope } \\ \text { Col I } & \text { Type I collagen } \\ \text { DT } & \text { Doubling time } \\ \text { ECM } & \text { Extracellular matrix } \\ \text { ELISA } & \text { Enzyme-linked immunosorbent assay } \\ \text { FBS } & \text { Fetal bovine serum } \\ \text { FT-IR } & \text { Fourier-transform infrared spectroscopy } \\ \text { HA } & \text { Hydroxyapatite } \\ \text { ICP-OES } & \text { Inductively coupled plasma spectrometry } \\ \text { IF } & \text { Immunofluorescence } \\ \text { IGF-1 } & \text { Insulin-like growth factor 1 } \\ \text { MC3T3-E1 } & \text { Mouse calvarial preosteoblast cell line } \\ \text { MSCs } & \text { Mesenchymal stem cells }\end{array}$




$\begin{array}{ll}\text { OC } & \text { Osteocalcin } \\ \text { PS } & \text { Polystyrene } \\ \text { PXRD } & \text { Powder X-ray diffraction } \\ \text { Runx-2 } & \text { Runt-related transcription factor 2 } \\ \text { TEM } & \text { Transmission electron microscope } \\ \text { VEGF } & \text { Vascular endothelial growth factor }\end{array}$

\section{References}

1. Velasco, M.A.; Narváez-Tovar, C.A.; Garzón-Alvarado, D.A. Design, materials, and mechanobiology of biodegradable scaffolds for bone tissue engineering. BioMed Res. Int. 2015, 2015. [CrossRef] [PubMed]

2. Przekora, A. Current trends in fabrication of biomaterials for bone and cartilage regeneration: Materials modifications and biophysical stimulations. Int. J. Mol. Sci. 2019, 20, 435. [CrossRef] [PubMed]

3. Evis, Z.; Webster, T.J. Nanosize hydroxyapatite: Doping with various ions. Adv. Appl. Ceram. 2011, 110, 311-321. [CrossRef]

4. O'Neill, E.; Awale, G.; Daneshmandi, L.; Umerah, O.; Lo, K.W.H. The roles of ions on bone regeneration. Drug Discov. Today 2018, 23, 879-890. [CrossRef] [PubMed]

5. Galli, S.; Naito, Y.; Karlsson, J.; He, W.; Miyamoto, I.; Xue, Y.; Andersson, M.; Mustafa, K.; Wennerberg, A.; Jimbo, R.; et al. Local release of magnesium from mesoporous $\mathrm{TiO}_{2}$ coatings stimulates the peri-implant expression of osteogenic markers and improves osteoconductivity in vivo. Acta Biomater. 2014, 10, 5193-5201. [CrossRef]

6. Yoshizawa, S.; Brown, A.; Barchowsky, A.; Sfeir, C. Magnesium ion stimulation of bone marrow stromal cells enhances osteogenic activity, simulating the effect of magnesium alloy degradation. Acta Biomater. 2014, 10, 2834-2842. [CrossRef] [PubMed]

7. Zreiqat, H.; Howlett, C.R.; Zannettino, A.; Evans, P.; Schulze-Tanzil, G.; Knabe, C.; Shakibaei, M. Mechanisms of magnesium-stimulated adhesion of osteoblastic cells to commonly used orthopaedic implants. J. Biomed. Mater. Res. 2002, 62, 175-184. [CrossRef]

8. Kwun, I.; Cho, Y.; Lomeda, R.R.; Shin, H.; Choi, J.; Kang, Y.; Beattie, J.H. Zinc deficiency suppresses matrix mineralization and retards osteogenesis transiently with catch-up possibly through Runx 2 modulation. Bone 2010, 46, 732-741. [CrossRef]

9. Seo, H.J.; Cho, Y.E.; Kim, T.; Shin, H.I.; Kwun, I.-S. Zinc may increase bone formation through stimulating cell proliferation, alkaline phosphatase activity and collagen synthesis in osteoblastic MC3T3-E1 cells. Nutr. Res. Pract. 2010, 4, 356-361. [CrossRef]

10. Yamaguchi, M.; Weitzmann, M.N. Zinc stimulates osteoblastogenesis and suppresses osteoclastogenesis by antagonizing NF-kB activation. Mol. Cell. Chem. 2011, 355, 179-186. [CrossRef]

11. Thein-Han, W.W.; Misra, R.D.K. Biomimetic chitosan-nanohydroxyapatite composite scaffolds for bone tissue engineering. Acta Biomater. 2008, 5, 1182-1197. [CrossRef] [PubMed]

12. Xiao, X.; Liu, R.; Huang, Q. Preparation and characterization of nano-hydroxyapatite/polymer composite scaffolds. J. Mater. Sci. Mater. Med. 2008, 19, 3429-3435. [CrossRef] [PubMed]

13. Iwai, S.; Shimizu, H.; Suzawa, Y.; Akashi, M.; Yura, Y. Hydroxyapatite agarose composite gels as a biochemical material for the repair of alveolar bone defects due to cleft lip and palate. J. Oral Maxillofac. Surg. Med. Pathol. 2015, 27, 637-644. [CrossRef]

14. Iwai, S.; Shimizu, H.; Takeshita, A.; Akashi, M.; Yura, Y. Translational research of HAp/agarose composite gel (HAp gel) used as a bone regenerative biomechanical material in jawbone defects. Int. J. Oral Maxillofac. Surg. 2013, 42, 1180-1181. [CrossRef]

15. Hu, J.; Zhu, Y.; Tong, H.; Shen, X.; Chen, L.; Ran, J. A detailed study of homogeneous agarose/hydroxyapatite nanocomposites for load-bearing bone tissue. Int. J. Biol. Macromol. 2016, 82, 134-143. [CrossRef] [PubMed]

16. Merlin Rajesh Lal, L.P.; Suraishkumar, G.K.; Nair, P.D. Chitosan-agarose scaffolds supports chondrogenesis of Human Wharton's Jelly mesenchymal stem cells. J. Biomed. Mater. Res. Part A 2017, 105, 1845-1855. [CrossRef] [PubMed]

17. Bazin, D.; Chappard, C.; Combes, C.; Carpentier, X.; Rouzière, S.; André, G.; Matzen, G.; Allix, M.; Thiaudière, D.; Reguer, S.; et al. Diffraction techniques and vibrational spectroscopy opportunities to characterise bones. Osteoporos. Int. 2009, 20, 1065-1075. [CrossRef] 
18. Haider, A.; Haider, S.; Han, S.S.; Kang, I.K. Recent advances in the synthesis, functionalization and biomedical applications of hydroxyapatite: A review. RSC Adv. 2017, 7, 7442-7458. [CrossRef]

19. Shepherd, J.H.; Shepherd, D.V.; Best, S.M. Substituted hydroxyapatites for bone repair. J. Mater. Sci. Mater. Med. 2012, 23, 2335-2347. [CrossRef]

20. Markovic, M.; Fowler, B.; Tung, M. Preparation and comprehensive characterization of a calcium hydroxyapatite reference material. J. Res. Natl. Inst. Stand. Technol. 2004, 109, 553-568. [CrossRef]

21. Hu, W.; Ma, J.; Wang, J.; Zhang, S. Fine structure study on low concentration zinc substituted hydroxyapatite nanoparticles. Mater. Sci. Eng. C 2012, 32, 2404-2410. [CrossRef]

22. Ren, F.; Xin, R.; Ge, X.; Leng, Y. Characterization and structural analysis of zinc-substituted hydroxyapatites. Acta Biomater. 2009, 5, 3141-3149. [CrossRef] [PubMed]

23. He, L.Y.; Zhang, X.M.; Liu, B.; Tian, Y.; Ma, W.H. Effect of magnesium ion on human osteoblast activity. Braz. J. Med. Biol. Res. 2016, 49, 1-6. [CrossRef] [PubMed]

24. Yusa, K.; Yamamoto, O.; Fukuda, M.; Koyota, S.; Koizumi, Y.; Sugiyama, T. In vitro prominent bone regeneration by release zinc ion from Zn-modified implant. Biochem. Biophys. Res. Commun. 2011, 412, $273-278$. [CrossRef] [PubMed]

25. Yoshizawa, S.; Brown, A.; Barchowsky, A.; Sfeir, C. Role of magnesium ions on osteogenic response in bone marrow stromal cells. Connect. Tissue Res. 2014, 55, 155-159. [CrossRef] [PubMed]

26. An, S.; Gong, Q.; Huang, Y. Promotive effect of zinc ions on the vitality, migration, and osteogenic differentiation of human dental pulp cells. Biol. Trace Elem. Res. 2017, 175, 112-121. [CrossRef] [PubMed]

27. Thian, E.S.; Konishi, T.; Kawanobe, Y.; Lim, P.N.; Choong, C.; Ho, B.; Aizawa, M. Zinc-substituted hydroxyapatite: A biomaterial with enhanced bioactivity and antibacterial properties. J. Mater. Sci. Mater. Med. 2013, 24, 437-445. [CrossRef] [PubMed]

28. Moon, M.Y.; Kim, H.J.; Choi, B.Y.; Sohn, M.; Chung, T.N.; Suh, S.W. Zinc promotes adipose-derived mesenchymal stem cell proliferation and differentiation towards a neuronal fate. Stem Cells Int. 2018, 2018, 1-9. [CrossRef] [PubMed]

29. Ullah, S.; Zainol, I.; Idrus, R.H. Incorporation of zinc oxide nanoparticles into chitosan-collagen 3D porous scaffolds: Effect on morphology, mechanical properties and cytocompatibility of 3D porous scaffolds. Int. J. Biol. Macromol. 2017, 104, 1020-1029. [CrossRef] [PubMed]

30. Tang, Z.; Li, X.; Tan, Y.; Fan, H.; Zhang, X. The material and biological characteristics of osteoinductive calcium phosphate ceramics. Regen. Biomater. 2018, 5, 43-59. [CrossRef] [PubMed]

31. Przekora, A. The summary of the most important cell-biomaterial interactions that need to be considered during in vitro biocompatibility testing of bone scaffolds for tissue engineering applications. Mater. Sci. Eng. C 2019, 97, 1036-1051. [CrossRef] [PubMed]

32. Jin, G.; Cao, H.; Qiao, Y.; Meng, F.; Zhu, H.; Liu, X. Osteogenic activity and antibacterial effect of zinc ion implanted titanium. Colloids Surf. B Biointerfaces 2014, 117, 158-165. [CrossRef] [PubMed]

33. Xu, H.H.; Wang, P.; Wang, L.; Bao, C.; Chen, Q.; Weir, M.D.; Chow, L.C.; Zhao, L.; Zhou, X.; Reynolds, M.A.; et al. Calcium phosphate cements for bone engineering and their biological properties. Bone Res. 2017, 5, 17056. [CrossRef] [PubMed]

34. Sun, M.; Chi, G.; Xu, J.; Tan, Y.; Xu, J.; Lv, S.; Xu, Z.; Xia, Y.; Li, L.; Li, Y.; et al. Extracellular matrix stiffness controls osteogenic differentiation of mesenchymal stem cells mediated by integrin $\alpha 5$. Stem Cell Res. Ther. 2018, 9, 52. [CrossRef] [PubMed]

35. Zhang, Y.; Xing, Y.; Li, J.; Zhang, Z.; Luan, H.; Chu, Z.; Gong, H.; Fan, Y. Osteogenesis-related behavior of MC3T3-E1 cells on substrates with tunable stiffness. Biomed Res. Int. 2018, 2018, 4025083. [CrossRef] [PubMed]

36. Hoppe, A.; Güldal, N.S.; Boccaccini, A.R. A review of the biological response to ionic dissolution products from bioactive glasses and glass-ceramics. Biomaterials 2011, 32, 2757-2774. [CrossRef]

37. Julien, M.; Khoshniat, S.; Lacreusette, A.; Gatius, M.; Bozec, A.; Wagner, E.F.; Wittrant, Y.; Masson, M.; Weiss, P.; Beck, L.; et al. Phosphate-dependent regulation of MGP in osteoblasts: Role of ERK1/2 and Fra-1. J. Bone Miner. Res. 2009, 24, 1856-1868. [CrossRef]

38. Kim, H.; Han, H.; Lee, K.; Lee, D.; Lee, J.W.; Jeon, H.; Cho, S.; Roh, H.; Kim, Y.; Seok, H.; et al. Comprehensive study on the roles of released ions from biodegradable $\mathrm{Mg}-5 \mathrm{wt} \% \mathrm{Ca}-1 \mathrm{wt} \% \mathrm{Zn}$ alloy in bone regeneration. J. Tissue Eng. Regen. Med. 2017, 11, 2710-2724. [CrossRef] 
39. Kolmas, J.; Pajor, K.; Pajchel, L.; Przekora, A.; Ginalska, G.; Oledzka, E.; Sobczak, M. Fabrication and physicochemical characterization of porous composite microgranules with selenium oxyanions and risedronate sodium for potential applications in bone tumors. Int. J. Nanomed 2017, 12, 5633. [CrossRef]

40. Przekora, A.; Ginalska, G. Enhanced differentiation of osteoblastic cells on novel chitosan/B-1,3-glucan/bioceramic scaffolds for bone tissue regeneration. Biomed. Mater. 2015, 10, 015009. [CrossRef]

(C) 2019 by the authors. Licensee MDPI, Basel, Switzerland. This article is an open access article distributed under the terms and conditions of the Creative Commons Attribution (CC BY) license (http://creativecommons.org/licenses/by/4.0/). 